University of Nebraska - Lincoln

DigitalCommons@University of Nebraska - Lincoln

\title{
Biodiversity maintenance mechanisms differ between native and novel exotic-dominated communities
}

\author{
Brian J. Wilsey \\ lowa State University \\ Terri B. Teaschner \\ lowa State University \\ Pedram P. Daneshgar \\ lowa State University \\ Forest I. Isbell \\ lowa State University \\ H. Wayne Polley \\ USDA-ARS Grassland, Soil and Water Research Laboratory, wayne.polley@ars.usda.gov
}

Follow this and additional works at: https://digitalcommons.unl.edu/usdaarsfacpub

Part of the Agricultural Science Commons

Wilsey, Brian J.; Teaschner, Terri B.; Daneshgar, Pedram P.; Isbell, Forest I.; and Polley, H. Wayne, "Biodiversity maintenance mechanisms differ between native and novel exotic-dominated communities" (2009). Publications from USDA-ARS / UNL Faculty. 428.

https://digitalcommons.unl.edu/usdaarsfacpub/428

This Article is brought to you for free and open access by the U.S. Department of Agriculture: Agricultural Research Service, Lincoln, Nebraska at DigitalCommons@University of Nebraska - Lincoln. It has been accepted for inclusion in Publications from USDA-ARS / UNL Faculty by an authorized administrator of DigitalCommons@University of Nebraska - Lincoln. 


\section{LETTER}

\section{Biodiversity maintenance mechanisms differ between native and novel exotic-dominated communities}

Brian J. Wilsey, ${ }^{1 *}$ Terri B. Teaschner, ${ }^{1}$ Pedram $\mathbf{P}$. Daneshgar, ${ }^{1}$ Forest I. Isbell ${ }^{1}$ and H. Wayne Polley ${ }^{2}$ ${ }^{1}$ Department of Ecology, Evolution and Organismal Biology, 253 Bessey Hall, lowa State University, Ames, IA 50011, USA

${ }^{2}$ Grassland, Soil and Water Research Laboratory, USDAARS, Temple, TX 76502, USA *Correspondene: E-mail: bwilsey@iastate.edu

\begin{abstract}
In many systems, native communities are being replaced by novel exotic-dominated ones. We experimentally compared species diversity decline between nine-species grassland communities under field conditions to test whether diversity maintenance mechanisms differed between communities containing all exotic or all native species using a pool of 40 species. Aboveground biomass was greater in exotic than native plots, and this difference was larger in mixtures than in monocultures. Species diversity declined more in exotic than native communities and declines were explained by different mechanisms. In exotic communities, overyielding species had high biomass in monoculture and diversity declined linearly as this selection effect increased. In native communities, however, overyielding species had low biomass in monoculture and there was no relationship between the selection effect and diversity decline. This suggests that, for this system, yielding behaviour is fundamentally different between presumably co-evolved natives and coevolutionarily naive exotic species, and that native-exotic status is important to consider.
\end{abstract}

\section{Keywords}

biodiversity loss, biodiversity-ecosystem functioning, grasslands, invasive species, net biodiversity effect, novel ecosystems, restoration ecology, species diversity, species richness, tallgrass prairie.

Ecology Letters (2009) 12: 432-442

\section{INTRODUCTION}

The homogenization of the earth's biota is affecting nearly every region of the earth (Mooney \& Drake 1986; Vitousek 1994; Brown 1995; Mack et al. 2000; Lockwood \& McKinney 2001; Olden \& Poff 2003). This homogenization is expected to increase due to the increased movement of people and goods between regions, and many exotic ('introduced' sometimes called 'invasive') species are having a negative economic impact (Pimentel et al. 2000). Introduced species have either been planted or favoured by the activities of humans, which has been described by Kareiva et al. (2007) as a domestication of nature. This is especially prevalent in grassland ecosystems, where exotic species have become common or even the dominant species in many areas (Gibson 2009; Caldwell et al. 1981; Christian \& Wilson 1999, Callaway \& Aschehoug 2000; Wilsey \& Polley 2003, Corbin \& D'Antonio 2004; Zavaleta \& Hulvey 2004; Gabbard \& Fowler 2007; Gendron \& Wilson 2007; Zavaleta \& Hulvey 2007; Wilsey 2005; Maron \& Marler 2008).
Conversion of native to exotic-dominated grasslands has occurred either by humans planting exotics that do not give way to natives over time or by exotics spreading to displace natives (Hobbs et al. 2006). For example, Kulmatiski (2006) found exotic grasslands persisting after 52 years on formerly tilled fields even when they were adjacent to nativedominated remnants. These exotic-dominated patches in modern landscapes are commonly called 'novel ecosystems' because they often contain species that have no shared evolutionary history (Chapin \& Starfield 1997; Hobbs et al. 2006; Mascaro et al. 2008). Conversion of grasslands can lead to a patchwork of native- and exotic-dominated patches interspersed with patches that contain a mixture of natives and exotics at the landscape scale.

There is some evidence that exotic ecosystems have lower diversity than native ones, even many years after abandonment from agriculture (e.g. Christian \& Wilson 1999). It is largely unknown whether the low diversity found in these environments is caused solely by higher resource availabilities or disturbance ('passengers' of change, MacDougal \& Turkington 2005), or if part of the effect is due to 
characteristics of the species themselves ('drivers' of change). High resource availabilities usually (e.g. Huenneke et al. 1990; Wedin \& Tilman 1996; Blumenthal et al. 2003), but not always favour exotic species (e.g. Gendron \& Wilson 2007). Determining whether the species themselves are an additional factor in causing exotic communities to have lower diversity than the native communities that they replace is an important and largely unanswered question. Observational studies of exotic invasions are helpful but they will not be able to entirely answer this question. Negative correlations between exotic species abundance and diversity could exist either because exotics are causing diversity to decline or because low diversity sites are more invadable (Levine \& D’Antonio 1999).

Species may coexist if tradeoffs in capturing multiple resources lead to complementary resource use and overyielding by low biomass species in mixture, and these effects may be lessened in novel exotic-dominated communities. Chesson (2000) developed a synthetic model of species coexistence that includes stabilizing (increasing negative intraspecific interactions relative to negative interspecific interactions) and equalizing (minimizing average fitness differences between species) mechanisms. Combining his ideas with components of the net biodiversity effect (Loreau \& Hector 2001), we have developed a new framework for testing species diversity maintenance in mixtures (Isbell et al. 2009). The framework predicts that species diversity will be maintained at a higher value when the complementarity effect is high due to greater niche partitioning or facilitation, when the selection effect is reduced, or when there are smaller differences in biomass among species (Isbell et al. 2009). Using this framework with a long-term experiment that varied species evenness and richness using random draws from a species pool of 10 native and three exotic species (Wilsey \& Polley 2004), we found that diversity was maintained more by stabilizing (or 'species interaction') mechanisms than by equalizing mechanisms (Isbell et al. 2009). Most importantly for the topic of this paper, we found that: (i) stabilizing mechanisms were due specifically to having a neutral or negative selection effect and were unrelated to the complementarity effect and (ii) the selection effect was positively correlated with the proportion of exotic species (Isbell et al. 2009). Thus, if exotic species have higher (Wilsey \& Polley 2006) and more similar aboveground growth rates than natives, then we would predict greater interspecific competition aboveground and lowered diversity due to the destabilizing effect associated with a positive selection effect. Native communities are predicted to have a more neutral selection effect and a positive complementarity effect, both of which should stabilize diversity above exotic levels.

The question of whether diversity is inherently lower in communities of exotic than native species can be addressed directly by comparing experimental communities over time in similar high resource conditions (where exotics tend to become established, Burke \& Grime 1996; Davis et al. 2000; Renne et al. 2006), which is what we have done here. We experimentally tested whether exotics can be drivers of species diversity change as native-dominated ecosystems are replaced by novel ones in modern landscapes. We hypothesized that resource partitioning is greater and the interspecific-intraspecific competition ratio is lesser among native species that have a shared evolutionary history than among comparable novel exotic-dominated communities. Exotic species were commonly introduced by humans to prevent erosion, or as pasture or garden plants, and we hypothesize that introductions were associated with human selection for traits (e.g. high aboveground growth rates and low root mass fraction, Wilsey \& Polley 2006) that are advantageous in single-species plantings on bare ground, but that have negative effects on diversity in mixture. High diversity native communities may contain a greater amount of functional variation among species and hence greater resource partitioning than novel ones (Parrish \& Bazzaz 1976); these differences are predicted to lead to less interspecific competition.

Here, we test the following hypotheses in a field experiment using a large species pool of 20 natives and 20 exotics: (i) native species communities maintain greater species diversity over time than comparable novel (exotic) communities and (ii) exotic species over-yield in mixture due to a strong selection effect (i.e. having highly productive species that do better than expected in mixture), whereas native species assemblages, due to their common evolutionary history, are characterized by having more complementary resource use among species. The exotic species in the study area have very different origins (Asia, South America, Africa or Europe). Thus, by comparing diversity decline in experimental plantings of native and novel (exotic) communities, we were able to directly test these predictions.

\section{METHODS}

\section{Study site and experimental design}

The MEND (maintenance of exotic vs. native diversity) study was conducted in the Blackland Prairie region of Texas. About $98 \%$ of the region was cultivated to produce cotton, sorghum, corn, wheat and forages during the latter part of the 19th and early part of the 20th centuries. However, now only about $50 \%$ of the area is used as cropland and much of the rest has returned to rangeland and oldfields dominated by a variety of mostly exotic species surrounding a few scattered unplowed remnants (Diggs $\mathrm{et}$ al. 1999). Fields located on lands owned by the USDA-ARS 
Grassland, Soil and Water Research Lab near Temple, Texas (Bell County) were used for the experiment (Wilsey \& Polley 2003, 2006). The site typically receives $879 \mathrm{~mm}$ of precipitation per year with a strong bimodal pattern consisting of a large peak in Spring and a smaller peak during Fall. The first year of the study (2007) was 45\% wetter than average $(1277.9 \mathrm{~mm})$, with a wetter than average March, May, June, July and August. The second year (2008, $453 \mathrm{~mm}$ through July) was $12 \%$ drier than average for January-July. The soils are Vertisol usterts.

All of the perennial exotic species that had appropriate native pairs were used in the study, based on grasslands in the region (Table 1, Diggs et al. 1999). Thus, the study was done to test the effects of exotics in general, and we did not exclude species that were exceptionally invasive or minimally invasive. All of the exotic species are found in grasslands and roadsides in the area (Table 1, Diggs et al. 1999); thus, no new exotics were introduced into plots. The twenty exotic species, which included many species that were widely distributed in North America, varied in their regional abundance from very common and frequent (e.g. Sorghum halepense and Botbriochloa ischaemum) to common and frequent in disturbed areas (e.g. Taraxacum officinale and Trifolium repens) to less common but readily escaping cultivation (e.g. Ruellia brittoniana Diggs et al. 1999). Native species paired with exotics were similarly variable in their frequency and abundance, ranging from common and frequent species, to species found in disturbed areas.

There were several advantages in using this site for testing hypotheses. First, the Blackland prairie system has long growing seasons and high net primary productivity (NPP), which leads to relatively rapid change in plant communities in the first two growing seasons (Wilsey \& Polley 2004; Isbell et al. 2009). Second, exotic species are from a variety of continental sources (Table 1), that is, they have no shared evolutionary history. Thus, we were comparing communities of species that do not share a common history (novel ecosystems dominated by exotics) to communities that do share a common history (natives). Fields in the area ranged from having a mean of $3 \%$ of NPP from exotic species (never plowed remnant areas, Polley et al. 2005) to patches within invaded fields having up to $99 \%$ of NPP from exotics (previously plowed areas, mean 70.4\%, 15 of 20 plots had

Table 1 Perennial exotic and native species, paired by phylogeny and growth form that were used in the experiment. Exotic species are defined as species not native to the region according to Diggs et al. (1999)

\begin{tabular}{|c|c|c|c|}
\hline $\begin{array}{l}\text { Scientific name } \\
\text { of exotic }\end{array}$ & Shared Taxon & $\begin{array}{l}\text { Place of origin } \\
\text { of exotic }\end{array}$ & Native pair \\
\hline \multicolumn{4}{|l|}{$\mathrm{C}_{4}$ grasses } \\
\hline Botbriochloa ischaemum ${ }^{*}, \uparrow$, & Tribe Andropogoneae & Asia & Schizachyrium scoparium $*$ \\
\hline Cynodon dactylon* & Tribe Cynodonteae & Africa & Buchloe dactyloides*, \\
\hline Eragrostis curvula, & Tribe Eragrostideae & Africa & Sporobolus asper*, $\uparrow, * *$ \\
\hline Panicum coloratum $\$$ & Genus Panicum & Africa & Panicum virgatum $\$$ \\
\hline Paspalum dilatatum* & Tribe Paniceae & South America & Eriocbloa sericeat \\
\hline Sorghum halepense*,†,** & Tribe Andropogoneae & Mediteranean & Sorghastrum nutans*, $\uparrow$ \\
\hline Paspalum notatum $₫$ & Genus Paspalum & Latin America & Paspalum floridanum* \\
\hline Dicantbium annulatum*,** & Tribe Andropogoneae & Africa, Asia & Andropogon gerardiit, \\
\hline \multicolumn{4}{|l|}{$\mathrm{C}_{3}$ grasses } \\
\hline Festuca arundinacea & Subfamily Pooideae & Europe & Elymus canadensis , \\
\hline Dactylis glomerataS & Subfamily Pooideae & Eurasia & Nassella luecotrichaฐ, ${ }^{* *}$ \\
\hline \multicolumn{4}{|l|}{ Forbs } \\
\hline Taraxacum officinale* & Asteraceae & Europe & Marshallia caespitosat \\
\hline Leucanthemum vulgare & Asteraceae & Eurasia & Ratibida columnifera \\
\hline Cichorium intybus $\$, \Phi$ & Asteraceae & Eurasia & Vernonia baldwinit \\
\hline Ruellia britonianat: & Genus Ruellia & E. Mexico & Ruellia bumilist:** \\
\hline Nepeta catarias, & Lamiaceae & Eurasia & Salvia azurea ${ }^{* *}$ \\
\hline Marrubium vulgare & Lamiaceae & Eurasia, Med. & Monarda fistulosat, \\
\hline \multicolumn{4}{|l|}{ Legumes } \\
\hline Medicago sativaS, & Subfamily Papilionoideae & Eurasia & Dalea purpurea\} $\\
{\hline \text { Trifolium repens\$ }} &{\text { Subfamily Papilionoideae }} &{\text { Europe }} &{\text { Dalea candidum } 5} \\
{\hline \text { Lotus corniculatus } ₫} &{\text { Fabaceae }} &{\text { Eurasia }} &{\text { Desmanthus illinoensis } \$} \\
{\hline \text { Coronilla varia }} &{\text { Subfamily Papilionoideae }} &{\text { Europe, Med. }} &{\text { Astragalus canadensis }} \\
$\hline
\end{tabular}

Propagule source: *field collected, vegetative; †field collected, seed; $\$$ commercial suppliers, vegetative; \commercial suppliers, seed. Mean yielding in mixtures: $\uparrow$ significant underyielding; ${ }^{* *}$ significant overyielding. 
$>50 \%$ exotic NPP, eight of 20 had $>90 \%$ exotic NPP, data from Wilsey \& Polley 2003).

Data from intact systems (Wilsey \& Polley 2003) were used to create communities with realistic species diversities and plant densities. For example, $0.5 \mathrm{~m}^{2}$ quadrats in a native Blackland prairie in Texas had a Simpson's diversity of 4.14.8 and a species richness of 11.3-13.6 compared with a diversity of 1.9-3.4 and a species richness of 4.7-8.6 in nearby B. ischaemum dominated (i.e. exotic) grasslands (Wilsey \& Polley 2003). The number of species and relative abundances used in the experiment bracketed these estimates of species diversity.

The experiment involved planting seedlings of either all native or all exotic species into plots at a controlled initial density. Equal-mass seedling transplants were grown in potting soil-sand mixtures in greenhouses and were then transplanted while very small into an abandoned pasture dominated by the exotic $\mathrm{C}_{4}$ grass Botbriochloa ischaemum. B. ischaemum was removed from $1 \times 1 \mathrm{~m}$ plots (plus a $25 \mathrm{~cm}$ buffer) with glyphosate herbicide while keeping it intact in alleyways. Seedlings were watered during the first 2 weeks to ensure establishment. Time zero biomass did not vary between native and exotic species $\left(F_{1,19}=0.1, P=0.96\right)$. Plots were weeded (i.e. volunteer seedlings were removed when very small) as necessary.

Plots were planted as either monocultures or mixtures of nine species at a planting density of 72 plants per $1 \mathrm{~m}^{2}$ plot. Previous research has shown that results from replacement designs can vary with density, especially when very low plant densities are used (Gibson et al. 1999; Polley et al.2003). Here, a density of 72 per $\mathrm{m}^{2}$ was used based on typical densities measured in a prairie remnant dominated by Schizachyrium scoparium (Losure et al. 2007). Due partially to the higher than average precipitation in year 1 , this density was high enough for full canopies to develop within the first growing season in mixtures. Mean light levels at soil surface $(1-\mathrm{cm}$ height, measured with a Decagon 1-m ceptometer) during September of year 1 were $13.9 \%(1.7 \mathrm{SE}, n=15)$ in exotic and $29.0 \%(3.7$ $\mathrm{SE}, n=15)$ in native mixtures. During September of year 2 , light at the soil surface was $27.3 \%$ (3.1 SE) and 26.0\% (3.6 SE) in exotic and native mixtures, respectively.

In this system, as in many prairie systems (Turner \& Knapp 1996), grasses make up the majority of biomass. To equalize initial relative abundances in mixtures, we planted each plot with 10 plants of each of four $C_{4}$ grass species (each grass species equally abundant), eight plants of one $\mathrm{C}_{3}$ grass species and six plants each of each of four forb species (three non-leguminous and one leguminous forb, each species equally abundant). This gives a realistic proportion of each functional group based on previous work in this system (Wilsey \& Polley 2003).

Plots were planted so that they had either all exotic or all native species. Exotics and natives were paired to prevent the confounding effects of functional group and phylogenetic differences (Agrawal \& Kotanen 2003). Seven random draws were made from the native-exotic perennial species list from Table 1 to vary species composition among mixtures. Draws were done so that exotic-native pairs were always selected together. There were 2-3 replicates of each random draw $\times 7$ draws $\times 2$ native-exotic status for 30 mixture plots total. All treatments were randomly assigned to plots. Seed or vegetative propagules for all species were hand-collected or purchased from local seed companies, with only local genotype seed used for native species (Table 1). The plots were planted during 19-24 April 2007, and replanted in early May after heavy rain washed away some plants from the original plantings.

The hypothesis that exotic species will show a stronger selection and a weaker complementarity effect was tested by comparing monocultures to their corresponding mixtures. Monoculture plots were established at the same time and in the same manner as mixtures (i.e. 72 plants per $1 \mathrm{~m}^{2}$ plot. We planted 1-2 replicates of each of the 40 species (58 total). A relatively low number of replicates enabled us to prevent over-representation of monocultures (Schmid et al. 2008). Species identity treatments were randomly applied to plots.

\section{Sampling design}

Plots were harvested at the end of the first growing season for peak aboveground biomass estimates. Aboveground biomass was sorted by species, dried and weighed. Species diversity measures [richness (S), Simpson's diversity $\left(1 / \Sigma \mathrm{pi}^{2}\right)$ and evenness $\left(1 / \Sigma \mathrm{pi}^{2}\right) / \mathrm{S}$ ] were estimated with biomass data in year 1 and with a non-destructive point intercept technique during early July of year 2. Species richness, which was estimated by noting all species in the plot, was ln-transformed for statistical analysis. Abundance of each species was estimated by dropping point intercept pins 25 times in a systematic fashion in the inner $80 \times 80 \mathrm{~cm}$ portion of each plot. All hits (i.e. multiple hits per pin) were counted so that data would correspond more closely to biomass estimates. Plant species that were present but that were not hit were given values of 0.5 hits.

\section{Components of the net biodiversity effect}

The net biodiversity effect, which compares biomass in mixtures to expected biomass based on monocultures, quantifies the balance (or imbalance) between intra- to interspecific interaction strength (Loreau \& Hector 2001). Thus, the net biodiversity effect corresponds to the stabilizing effect of Chesson (2000). However, it is useful to partition the net biodiversity effect into a complementarity and a selection effect because these effects can have 
different impacts on diversity (Isbell et al. 2009). Furthermore, inherent variation in biomass among species (i.e. in monocultures, $\left(\mathrm{CV}_{\text {mono }}\right)$, a surrogate measure for the equalizing effect, could also influence these biodiversity effect components (Isbell et al. 2009). The complementarity effect $(S \overline{\Delta \mathrm{RY}} \bar{M})$ compares species growth in mixture to expected values of the weighted average monoculture of component species (Loreau \& Hector 2001). The selection effect $(\mathrm{S} \operatorname{cov}[\Delta \mathrm{RY}, \mathrm{M}])$ is calculated as the covariance between monoculture yield of each species $(\mathrm{M})$ and their relative yield in mixture $(\Delta \mathrm{RY})$ (Loreau \& Hector 2001). A positive selection effect means that productive species overyield in mixture, which is predicted to cause diversity to decline as overyielding species become more dominant in mixture. On the other hand, a negative selection effect could prevent diversity decline because low productivity species are overyielding in mixture (Isbell et al. 2009). Both positive and negative selection effects have been found in earlier studies (e.g. Loreau \& Hector 2001; Polley et al. 2003; Isbell et al. 2009). A larger complementarity effect should reduce diversity loss when niche partitioning and/or facilitation is occurring in all species (Loreau \& Hector 2001). All of these measures could be related to variation in biomass among species $\left(\mathrm{CV}_{\text {mono }}\right)$.

When we conducted the net biodiversity calculations, expected yields were not normally distributed, especially in plots where a single species had much higher than expected yielding behavior (i.e. when a single species had a disproportionate effect on the mean). For this reason, the analysis of complementarity was estimated with the median as well as the mean value. In some plots, using the median instead of the mean changed a negative value to a positive value and vice versa. A median-based approach has the advantage of using estimates that are truly in the middle of the distribution for complementarity calculations, but it has the disadvantage of producing values that do not sum to the net biodiversity effect when added to the selection effect.

\section{Statistical analyses}

Experiments were analysed with two-way mixed model ANOVA using a completely randomized design. Because native and exotic species are paired, the ANOVA took into account this pairing to compare differences in response variables (biomass, species diversity measures, net biodiversity effects) between native and exotic pairs. The ANOvA included species draw $(7$ d.f.) as a random term, origin (native vs. exotic, 1 d.f.) as a fixed term, origin $\times$ draw (error term for origin) and replicate(draw $\times$ origin; error term for origin $\times$ draw) using type 3 sums of squares with Proc Mixed in SAS (Littell et al. 2002). 'Origin' tests for differences between native and exotic species and commu- nities and 'origin $\times$ draw' tests whether origin effects vary across random draws (i.e. with species composition). These tests were conducted separately for mixtures and monocultures because the draws/pairs were not crossed between the two richness levels. Draws (mixtures) and pairs (monocultures) were treated as a random term in the analyses to be able to make broader inferences about exotic species in general and to ensure that any specific species was not included in all mixtures. Diversity components from years 1 to 2 were analysed separately due to the difference in techniques (i.e. between biomass harvests and point intercept). Overyielding for individual species $\left[\left(Y_{\text {observed }}-Y_{\text {expected }}\right) / Y_{\text {expected }}\right]$ was tested by comparing mean yielding values to zero with $t$-tests. ANCOVA with biomass (years 1 and 2) or total point-intercept hits (year 2) as covariates, was used to determine if differences still existed between native and exotic communities after differences in biomass were taken into account (Sokal \& Rohlf 1997, p. 518). Intercorrelations among variables (Pearson's) were calculated to address how biomass differences among species (e.g. $\mathrm{CV}_{\text {mono }}$ ) translate into complementarity or selection effects.

\section{RESULTS}

\section{ANPP}

Exotics had greater peak aboveground biomass than natives at the end of the first growing season, and the difference was larger in mixtures than in monocultures (Fig. 1). Biomass was greater on average for exotic than native species monocultures, although the difference was not significant $\left(F_{1,19}=3.7, P=0.07\right)$. However, the difference

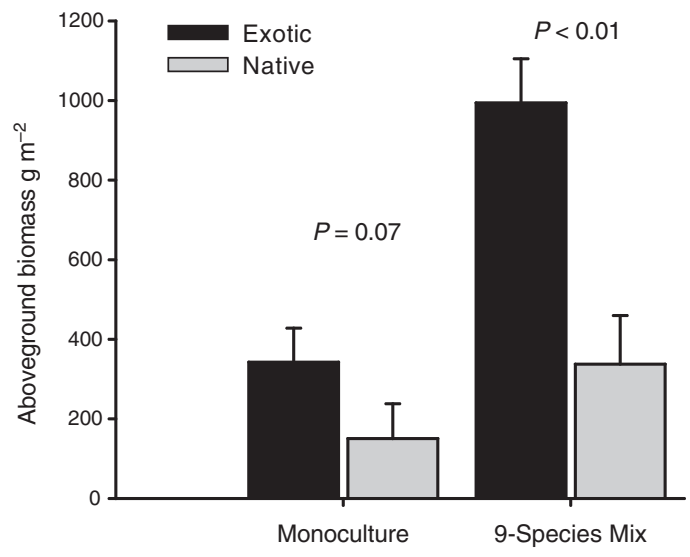

Figure 1 Peak aboveground biomass between monocultures and nine-species mixtures planted with all exotic species or all native species in a common environment after the first growing season. Native and exotic species were paired based on their growth form and phylogeny (Table 1). 
was significant in mixtures, where there was a threefold increase in peak biomass in exotics over natives $\left(F_{1,6}=17.7, P<0.01\right)$. Differences in biomass between natives and exotics were independent of the presence of specific species, i.e. they were consistent across species draws (origin $\times$ draw interaction, mixtures $F_{6,16}=1.9$; monocultures $F_{19,17}=1.7$, both $P$-values $\left.>0.05\right)$.

\section{Species diversity and net biodiversity effects}

Species diversity decline was rapid during the first growing season and the decline was greater in exotic than in native mixtures. The magnitude of the decline also varied across draws (i.e. with species composition). There was a significant difference in species diversity (origin $F_{1,6}=3.4$, $P=0.11$, origin $\times$ draw $\left.F_{6,16}=3.7, P<0.05\right)$ and evenness (origin $F_{1,6}=2.7, P=0.15$, origin $\times$ draw $F_{6,16}=2.8$, $P<0.05)$ in year 1 , but the differences observed varied across draws. Diversity was significantly lower in some draws of exotics (mean 1.74, $0.24 \mathrm{SE}$ ) than natives (2.37, $0.24 \mathrm{SE}$ ) by the end of the first growing season, and this difference was related to drops in evenness (exotics 0.228, natives $0.307,0.034 \mathrm{SE}$ ) and not richness (exotics 7.78, natives $7.98,0.25 \mathrm{SE}$ ). Species richness was not different between exotic and native communities in year 1 in any draws (origin $F_{1,6}=0.3, \quad P=0.58, \quad$ origin $\times$ draw $\left.F_{6,16}=1.1, P=0.43\right)$. Differences in diversity between natives and exotics could be explained by differences in aboveground biomass in year 1: significant interactions between origin and draw were not significant after taking into account aboveground biomass (ANCOVA, diversity: origin $\times$ draw, $P=0.09$, biomass, $P=0.10$; evenness: origin $\times$ draw, $P=0.16$, biomass, $P=0.08$ ).

By the middle of the second growing season, all diversity measures were significantly affected by treatments. Diversity (origin $F_{1,6}=10.3, P<0.05$ ) and richness (origin $F_{1,6}=9.1, P<0.05$ ) were 40 and $18 \%$ lower, respectively, in exotic than native communities (Fig. 2). These differences were more pronounced in some draws than in others, but this interaction effect was weaker than it was in year 1 (diversity, origin $\times$ draw $F_{6,16}=2.7$, $P=0.053$, richness, origin $\times$ draw $F_{6,16}=3.6, P<0.05$, Fig. 3). Evenness also differed between natives and exotics (origin $F_{1,6}=3.1, P=0.13$ ), but only in some draws (origin $\times$ draw $F_{6,16}=4.0, P<0.05$, data not shown). In contrast to first year results, the differences in diversity during year 2 were still significant after taking into account aboveground biomass from year 1 (ANCOVA, diversity: origin, $P=0.03$, biomass, $P=0.89$; richness: origin, $P=0.05$, biomass, $P=0.90)$ or total number of point intercept hits in year 2 (ANCOVA, diversity: origin, $P=0.01$, intercept hits, $P=0.13$; richness: origin, $P=0.1$, intercept hits, $P=0.06)$.

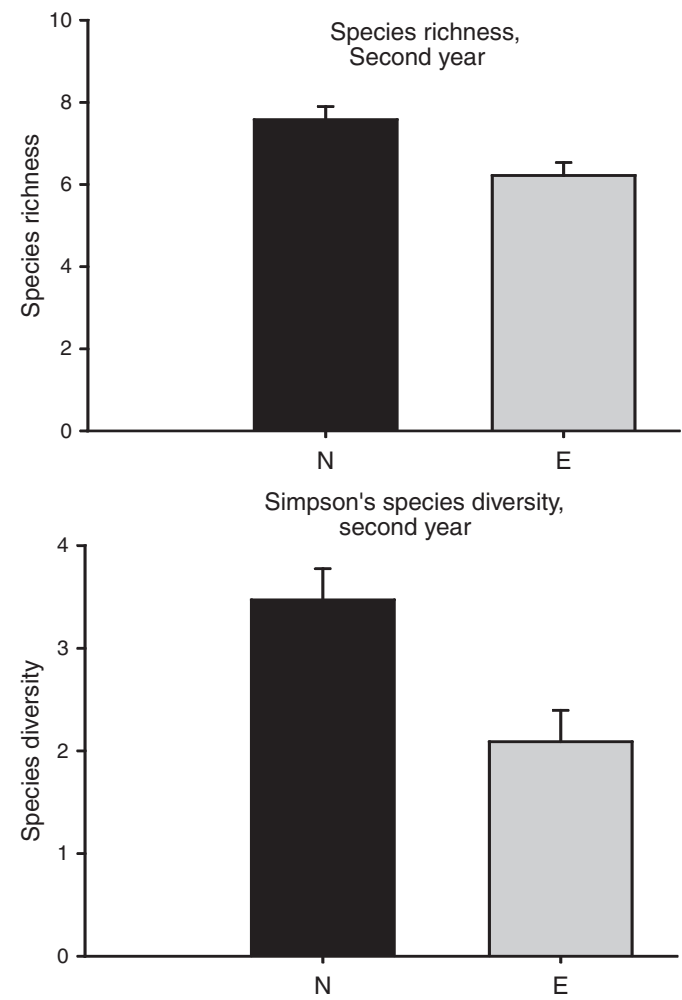

Figure 2 Mean (+SE) species diversity (Simpson's index) and richness between exotic and native plant communities in the second growing season. Plots were planted with equal-mass transplants of nine species (original Simpson's was 8.5) while controlling for species growth form and phylogeny between native and exotic mixtures.

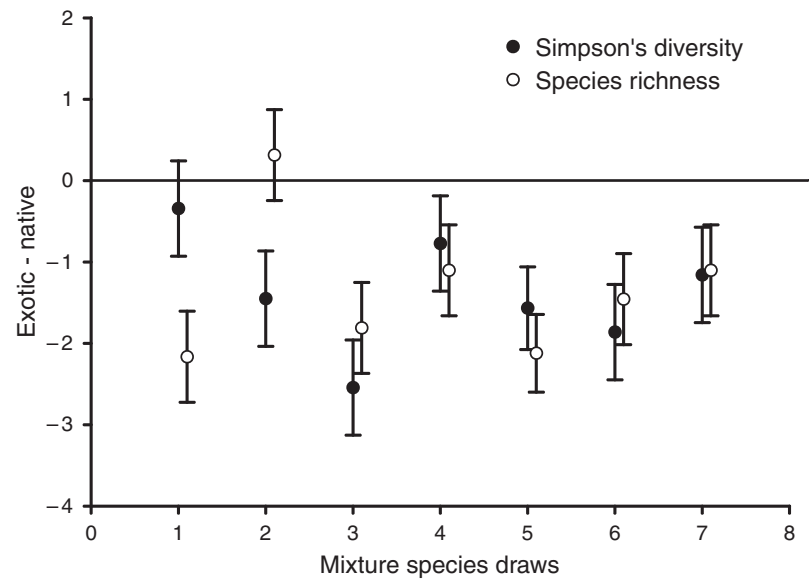

Figure 3 Absolute differences in species diversity and richness between experimental mixtures (draws) planted with all exotic or all native species in a common environment (best linear unbiased estimates \pm SE, $n=2-3$ per draw) during the second growing season. Line at 0 denotes no difference and values below the line indicate that diversity was lower in exotics than in natives. Native and exotic species were always selected as pairs based on their growth form and phylogeny (Table 1). 
There were also very large differences in net biodiversity effects between native and exotic communities (NBE: 507.7 in exotics, 129.7 in natives, $\mathrm{SE}=83.1$, origin $F_{1,6.1}=10.4$, $P<0.05)$, primarily due to differences in the selection effect (Fig. 4, $F_{1,6.1}=21.1, P<0.01$ ). The selection effect was significantly positive in the exotic communities $[352.7 \pm 79.3$ (SE)], whereas it was negative in native communities $[-160.8 \pm 79.3(\mathrm{SE})]$. Thus, the positive selection effect destabilized diversity in exotic communities because species that overyielded tended to have high biomass. In native communities, the negative selection effect stabilized diversity because overyielding species tended to have low biomass. Both native and exotic communities

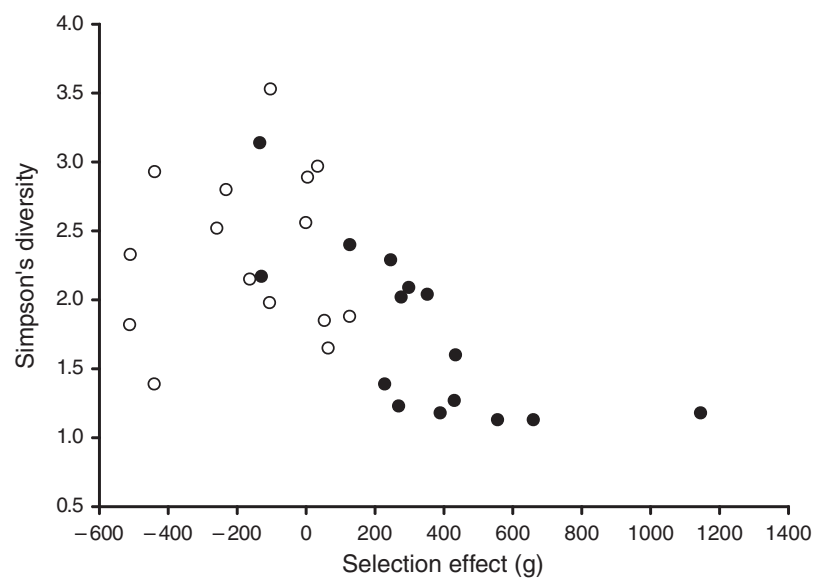

Figure 4 Relationship between species diversity and the selection effect in experimental mixtures of all native (open circles) or exotic (closed circles) species. Overyielding was found in low biomass species in native communities, which produced a negative mean selection effect. In exotic communities, overyielding was found in high biomass species, which produced a positive mean selection effect. had a significant complementarity effect when mean yielding was used, and there was no significant difference found between the two groups (159.2 in exotics, 289.1 in natives, $\left.\mathrm{SE}=96.9, F_{1,6.1}=1.2, \quad P<0.32\right)$. However, when the median was used rather than the mean for yielding, the complementarity effect was not significantly different from zero in either case ( -119.7 for exotics, 52.73 for natives, $\mathrm{SE}=59.5)$, and the difference between natives and exotics was marginally different $\left(F_{1,6}=4.2, P=0.09\right)$. Differences in net biodiversity effects were consistent across draws (origin $\times$ draw, $\mathrm{NBE} F_{6,16}=1.0, P=0.47$, selection $F_{6,16}=$ 2.3, $P=0.09$, complementarity $F_{6,16}=1.8, P=0.16$, complementarity with median $F_{6,16}=1.1, P=0.40$ ).

There were vastly different relationships between net biodiversity effects and species diversity decline between exotic and native communities (Table 2), with the selection effect being more important in exotic and the complementarity effect being more important in native communities. Diversity decline in exotics was only associated with the selection effect, with diversity declining steeply as the selection effect became more positive (Fig. 4). The selection effect accounted for $50 \%$ of the variation in exotic diversity decline. Relationships were not significant between monoculture biomass $\mathrm{CV}_{\text {mono }}$ (equalizing effects) or the complementarity effect and diversity decline in exotic communities, nor were the $\mathrm{CV}_{\text {mono, }}$ selection and complementarity effects significantly related to one another (Table 2). The NBE was correlated with the selection $(r=0.85, P<0.01)$ and the complementarity effect $(r=0.78, P<0.01)$ except when it was calculated with the median $(r=0.44, P=0.10$ all $n=15)$. In native communities, there were no significant relationships between predictor variables and diversity. However, net biodiversity effects were significantly correlated with one another and with $\mathrm{CV}_{\text {mono. }} \mathrm{NBE}$ was significantly correlated only with the complementarity effect $r=0.79, \quad P<0.01, \quad r=0.68, \quad P<0.01$ with median,

Table 2 Results of correlation analysis of diversity (dependent variable) and net biodiversity variables in paired native vs. exotic experimental grassland mixtures after the first growing season. Variables were biomass CV for monocultures for each species in the mixture (equalizing effect), the selection effect (destabilizing when positive, stabilizing when negative), the complementarity effect (stabilizing effect, using mean overyielding) and species diversity (Simpson's $1 / D$ )

\begin{tabular}{lllll}
\hline Origin & Independent variable & $r$ & Intercorrelations & $r$ \\
\hline Native & CV mono & 0.01 & CV-Selection & $-0.64^{* *}$ \\
& Selection & 0.08 & Selection-Complementarity & $-0.76^{* *}$ \\
Exotic & Complementarity & -0.05 & CV-Complementarity & $0.59^{*}$ \\
& CV & -0.34 & CV-Selection & 0.14 \\
& Selection & $-0.71^{* * *}$ & Selection-Complementarity & 0.33 \\
& Complementarity & -0.03 & CV-Complementarity & 0.34 \\
\hline
\end{tabular}

$* 0.05<P<0.10$.

$* * 0.01<P<0.05$.

$* * * P<0.01$. 
selection $r=-0.21$, all $n=15)$. Variation among species $\left(\mathrm{CV}_{\text {mono }}\right)$ was positively correlated with the complementarity effect and negatively correlated with the selection effect (Table 2). The selection effect was negatively correlated with the complementarity effect. Thus, there tended to be greater complementarity and a more negative selection effect as differences in biomass among species increased, but in natives only.

There were also important differences in the types of species that had the largest over- and underyielding between exotic and native communities (Table 1). The $\mathrm{C}_{4}$ grasses Sorghum halepense and Dicanthium annulatum consistently overyielded in exotic communities, with mean yielding of 4.5 and 2.2 respectively. These species commonly dominate exotic grasslands. A variety of species underyielded in exotic communities, including the legumes Lotus corniculata and Medicago sativa. In native communities, overyielding species included a $\mathrm{C}_{3}$ grass (Nassella leucotricha 11.9), two forbs (Ruellia humilis, 10.6; Salvia azurea, 6.5) and a $\mathrm{C}_{4}$ grass (Sporobolus compositus, 0.8); these species are typically subordinate species in intact systems. A variety of native species underyielded significantly, but none of them were legumes.

\section{DISCUSSION}

Using a large species pool of 20 native and 20 exotic grassland species, many of which are widely distributed in North America, we found differences in peak aboveground biomass in the first year and species diversity by the second year between comparable native and exotic 9-species communities while controlling for soil type, growth form and phylogeny. The difference in biomass was greatly enhanced when species grew in mixture. Importantly, we found for the first time that yielding behaviour is different between native and novel (exotic) communities, with overyielding by high biomass species in exotic communities and by low biomass species in native communities. Diversity decline was greater in exotic communities, and this drop was related to this overyielding behaviour (i.e. to the positive selection effect). Diversity differences between native and exotic communities were within the range of differences (c. $40 \%)$ seen between intact native and novel exoticdominated systems (Wilsey \& Polley 2003). Taken together, these results suggest that co-evolved species can differ from coevolutionarily naive species in the nature of their interactions after community assembly as hypothesized by Thompson et al. (2001).

Higher interspecific-intraspecific competition ratios due to a positive selection effect in exotic communities may have occurred because exotic species had higher aboveground growth rates than natives in year 1 (Daehler 2003; Vilà \& Weiner 2004; Wilsey 2005; Bossdorf et al. (2005) Blumenthal \& Hufbauer 2007; Maron \& Marler 2008).
Exotic species can have higher aboveground growth rates due to a variety of reasons, including release from enemies (e.g. Mitchell \& Power 2003), plant-soil feedbacks due to pathogen : mutualist ratios (e.g. Bever 2003; Wolfe \& Klironomos 2005; Levine et al. 2006), release from producing costly anti-herbivore or pathogen compounds (Blossey \& Nötzold 1995), due to microevolution of growth traits (Hierro et al. 2005) or other reasons (Vilà \& Weiner 2004). Regardless of the reason behind the higher aboveground growth rate in exotic species (which was not addressed here), the key issue for diversity maintenance theory is that diversity declined more rapidly in communities of exotic than native species, and the yielding behaviour behind the declines were different between native and exotic communities. The difference in aboveground biomass between exotic and native communities was much greater in mixtures (a statistically significant threefold difference) than between exotic and native monocultures (a non-significant twofold difference) in year 1 . This aboveground biomass difference explained differences in year 1 diversity levels but did not explain differences by the second year (ANCOVA results), which suggests that there was more to the differences in diversity between native and exotic communities than simple peak biomass differences. However, peak biomass does not necessarily correspond to early season growth rates, which might differ between natives and exotics to explain diversity declines. This needs to be tested in future studies.

Another interesting result was that differences in species diversity between natives and exotics varied across species draws. This result supports the suggestion that exotic species will vary in their effects on diversity as exotic systems replace native ones. By looking at differences in yielding behaviour between native and exotic communities, we can suggest a mechanism behind these differences. Declines in diversity were most rapid in exotic communities when a large positive selection effect occurred. When dominant grasses such as Sorgbum balepense or Dicanthium annulatum were present, these high biomass species overyielded in mixture, leading to greater drops in diversity. Differences in biomass among exotic species (i.e. monoculture $\mathrm{CV}$ ) were not correlated with net biodiversity effects. Thus, diversity decline was not prevented by equalizing mechanisms, and biomass differences among species did not translate directly into diversity declines. The key to understanding diversity decline in exotic communities was in how species interacted in mixture, with diversity decline being mostly affected by destabilizing effects associated with overyielding by high biomass (most often grass) species.

Differences in diversity between native and comparable exotic communities could be explained by differences in intercorrelations among variables. In native communities, diversity was higher on average and diversity declines were 
unrelated to net biodiversity effects. Overyielding species tended to have low biomass (i.e. a negative selection effect). Furthermore, differences in biomass among species $\left(\mathrm{CV}_{\text {mono }}\right)$ were highly correlated with net biodiversity effects which further stabilized diversity. In draws/plots with high biomass variation among species, differences among species tended to translate into a greater complementarity and a smaller selection effect. This suggests that differences among species were associated with greater resource partitioning or facilitation in native communities, which tended to stabilize diversity. The native species that consistently overyielded tend to be subordinate species in intact systems in the area (Wilsey \& Polley 2003; Polley et al. 2005).

A possible mechanism behind these results is that subordinate native species are co-evolved to have higher shade tolerance than comparable exotic species, and this should be tested directly in future studies. Most exotic species were introduced as forage species (grasses and legumes) or as garden herbs (forbs). We hypothesize that there was human selection for high aboveground biomass production and low shade tolerance when exotics were introduced, both traits being associated with growth in grazed-pasture or garden situations. Thus, when these species became naturalized, we would expect them to respond differently in mixture than comparable native species. High aboveground biomass in some but not all exotic species would cause exotics to have greater interspecific-intraspecific competition ratios compared with natives, which is what we found here.

Our experimental design allowed direct comparisons between native and novel (exotic-dominated) plant communities by pairing species within a given taxon, functional group and growth form. All species used were perennials. This allowed us to compare natives and exotics without these confounding factors, but it may have led to an underestimate of the actual differences between native and exotic communities in situations where exotics are from a different functional group or have a different growth form than the natives that they are replacing (Strauss et al. 2006). This possibility can be addressed in the future by combining our approach with companion comparative studies of invaded (exotic-dominated) and native environments.

Our results also point to the importance of species evenness as an important early indicator of diversity decline in response to exotic species invasion. If species richness had been our sole index of diversity in this study, we would have falsely concluded that diversity had not changed when it in fact had changed in some draws during year 1 (Chapin et al. 2000; Wilsey \& Potvin 2000; Wilsey \& Stirling 2007; Hillebrand et al. 2008). These initial drops in evenness preceded the drops in richness that occurred in the second year. It will be interesting to test how drops in species diversity will affect ecosystem processes in future years of the study.
In conclusion, our results suggest that for these 40 species in this system: (i) exotic species impact emergent properties at the community level that are important as novel (exotic) systems replace native ones, (ii) that plant-plant interactions and yielding behaviour are fundamentally different between coexisting and presumably co-evolved natives and coevolutionarily naive exotic species, and thus, that (iii) native-exotic status is important for understanding the mechanisms underlying biodiversity and ecosystem functioning, species diversity maintenance and other ecological questions. Nevertheless, this study was done on a single soil type and we did not vary herbivore or pathogen abundances or abiotic drivers. We suggest that our approach can be used in future studies to test whether differences between exotic and native communities vary in response to changes in resource supply associated with global climate change, with soil mutualist/pathogen feedbacks and with levels of disturbance.

\section{ACKNOWLEDGMENTS}

We thank Tim Dickson, Katherine Jones, Kyle Tiner and Chris Kolodziejczyk for help with planting. Helmut Hillebrand, Marcel Rejmánek and two anonymous referees made helpful comments on an earlier version of this manuscript. Funding was provided by the National Science Foundation (DEB0639417).

\section{REFERENCES}

Agrawal, A.A. \& Kotanen, P.M. (2003). Herbivores and the success of exotic plants: a phylogenetically controlled experiment. Ecol. Lett., 6, 712-715.

Bever, J.D. (2003). Soil community feedback and the coexistence of competitors: conceptual frameworks and empirical tests. New Phytol., 157, 465-473.

Blossey, B. \& Nötzold, R. (1995). Evolution of increased competitive ability in invasive nonindigenous plants: a hypothesis. J. Ecol., 83, 887-889.

Blumenthal, D.M. \& Hufbauer, R.A. (2007). Increased plant size in exotic populations: a common-garden test with 14 invasive species. Ecology, 88, 2758-2765.

Blumenthal, D.M., Jordan, N.R. \& Russelle, M.P. (2003). Soil carbon addition controls weeds and facilitates prairie restoration. Ecol. Appl., 13, 605-616.

Bossdorf, O., Auge, H., Lafuma, L., Rogers, W.E., Siemann, E. \& Prati, D. (2005). Phenotypic and genetic differentiation between native and introduced plant populations. Oecologia, 144, 1-11.

Brown, J.H. (1995). Macroecology. University of Chicago Press, Chicago, IL.

Burke, M.J.W. \& Grime, J.P. (1996). An experimental study of plant community invasibility. Ecology, 77, 776-791.

Caldwell, M.M., Richards, J.H., Johnson, D.A., Nowak, R.S. \& Dzurec, R.S. (1981). Coping with herbivory: photosynthetic capacity and resource allocation in two semiarid Agropyron bunchgrasses. Oecologia, 50, 14-24. 
Callaway, R.M. \& Aschehoug, E.T. (2000). Invasive plants versus their new and old neighbors: a mechanism for exotic invasion. Science, 290, 521-523.

Chapin, F.S. \& Starfield, A.M. (1997). Time lags and novel ecosystems in response to transient climatic change in arctic Alaska. Clim. Change, 35, 449-461.

Chapin, F.S., Zaveleta, E.S., Eviner, V.T., Naylor, R.L., Vitousek, P.M., Reynolds, H.L. et al. (2000). Consequences of changing biodiversity. Nature, 405, 234-242.

Chesson, P. (2000). Mechanisms of maintenance of species diversity. Annu. Rev. Ecol. Syst., 31, 343-366.

Christian, J.M. \& Wilson, S.D. (1999). Long-term ecosystem impacts of an introduced grass in the northern great plains. Ecology, 80, 2397-2407.

Corbin, J.D. \& D'Antonio, C.M. (2004). Competition between native perennial and exotic annual grasses: implications for an historical invasion. Ecology, 85, 1273-1283.

Daehler, C.C. (2003). Performance comparisons of co-occurring native and alien invasive plants: implications for conservation and restoration. Annu. Rev. Ecol. Evol. Syst., 34, 183-211.

Davis, M.A., Grime, J.P. \& Thompson, K. (2000). Fluctuating resources in plant communities: a general theory of invasibility. J. Ecol., 88, 528-534.

Diggs, G.M., Lipscomb, B.L. \& O’Kennon, R.J. (1999). Shinner's and Mahler's Illustrated Flora of North Central Texas. Botanical Research Institute of Texas, Fort Worth, TX.

Gabbard, B.L. \& Fowler, N.L. (2007). Wide ecological amplitude of a diversity-reducing invasive grass. Biol. Invasions, 9, 149160.

Gendron, F. \& Wilson, S.D. (2007). Responses to fertility and disturbance in a low-diversity grassland. Plant Ecol., 191, 199_ 207.

Gibson, D.J. (2009). Grasses and Grassland Ecology. Oxford University Press Inc, New York.

Gibson, D.J., Connolly, J., Hartnett, D.C. \& Weidenhauser, J.D. (1999). Design for greenhouse studies of interactions between plants. J. Ecol., 87, 1-6.

Hierro, J.L., Maron, J.L. \& Callaway, R.M. (2005). A biogeographic approach to plant invasions: the importance of studying exotics in their introduced and native range. J. Ecol., 93, 5-15.

Hillebrand, H., Bennett, D.M. \& Cadotte, M.W. (2008). Consequences of dominance: a review of evenness effects on local and regional ecosystem processes. Ecology, 89, 15101520.

Hobbs, R.J., Arico, S., Aronson, J., Baron, J.S., Bridgewater, P., Cramer, V.A. et al. (2006). Novel ecosystems: theoretical and management aspects of the new ecological world order. Glob. Ecol. Biogeogr., 15, 1-7.

Huenneke, L.F., Hamburg, S.P., Koide, R., Mooney, H.A. \& Vitousek, P. (1990). Effects of soil resources on plant invasion and community structure in California serpentine grassland. Ecology, 71, 478-491.

Isbell, F.I., Polley, H.W. \& Wilsey, B.J. (2009). Species interaction mechanisms maintain grassland plant species diversity. Ecology (in press).

Kareiva, P., Watts, S., McDonald, R. \& Boucher, T. (2007). Domesticated nature: shaping landscapes and ecosystems for human welfare. Science, 316, 1866-1869.

Kulmatiski, A. (2006). Exotic plants establish persistent communities. Plant Ecol., 187, 261-275.
Levine, J.M. \& D’Antonio, C.M. (1999). Elton revisited: a review of evidence linking diversity and invasibility. Oikos, 87, 1526.

Levine, J.M., Pachepsky, E., Kendall, B.E., Yelenik, S.G. \& Hille Ris Lambers, J. (2006). Plant-soil feedbacks and invasive spread. Ecol. Lett., 9, 1005-1014.

Littell, R.C., Stroup, W.W. \& Freund, R.J. (2002). SAS for Linear Models, 4th edn. SAS Institute Inc, Cary, NC.

Lockwood, J.L. \& McKinney, M.L. (2001). Biotic Homogenization. Klewer Academic/Plenum Publishers, New York.

Loreau, M. \& Hector, H. (2001). Partitioning selection and complementarity in biodiversity experiments. Nature, 412, 72-76.

Losure, D.A., Wilsey, B.J. \& Moloney, K.A. (2007). Evennessinvasibility relationships differ between two extinction scenarios in tallgrass prairie. Oikos, 116, 87-98.

MacDougal, A.S. \& Turkington, R. (2005). Are invasive species the drivers or the passengers of change in degraded ecosystems? Ecology, 86, 42-56.

Mack, R.N., Simberloff, D., Lonsdale, W.M., Evans, H., Clout, M. \& Bazzaz, F.A. (2000). Biotic invasions: causes, epidemiology, global consequences and control. Ecol. Appl., 10, 689-710.

Maron, J.L. \& Marler, M. (2008). Effects of native species diversity and resource additions on invader impact. Am. Nat., 172, S18S33.

Mascaro, J., Becklund, K.K., Hughes, R.F. \& Schnitzer, S.A. (2008). Limited native plant regeneration in novel, exoticdominated forests in Hawai'i. For. Ecol. Manage., 256, 593606.

Mitchell, C.E. \& Power, A.G. (2003). Release of invasive plants from fungal and viral pathogens. Nature, 421, 625-627.

Mooney, H.A. \& Drake, J.A. (1986). Ecology of Biological Invasions of North America and Hawaii. Springer-Verlag, New York, NY.

Olden, J.D. \& Poff, N.L. (2003). Toward a mechanistic understanding and prediction of biotic homogenization. Am. Nat., 162, 442-460.

Parrish, J.A.D. \& Bazzaz, F.A. (1976). Underground niche separation in successional plants. Ecology, 57, 1281-1288.

Pimentel, D., Lach, L., Zuniga, R. \& Morrison, D. (2000). Environmental and economic costs of non-indigenous species in the United States. Bioscience, 50, 53-65.

Polley, H.W., Wilsey, B.J. \& Derner, J.D. (2003). Do plant species evenness and plant density influence the magnitude of selection and complementarity effects in annual plant species mixtures? Ecol. Lett., 6, 248-256.

Polley, H.W., Wilsey, B.J. \& Derner, J.D. (2005). Patterns of plant species diversity in remnant and restored tallgrass prairies. Restor. Ecol., 13, 480-487.

Renne, I.J., Tracy, B.F. \& Colonna, I.A. (2006). Shifts in grassland invasibility: effects of soil resources, disturbance, composition, and invader size. Ecology, 87, 2264-2277.

Schmid, B., Hector, A., Saha, P. \& Loreau, M. (2008). Biodiversity effects and transgressive overyielding. J. Plant Ecol., 1, 95-102.

Sokal, R.R. \& Rohlf, F.J. (1997). Biometry, 3rd edn. W.H. Freeman and Company, New York, NY.

Strauss, S.Y., Webb, C.O. \& Salamin, N. (2006). Exotic taxa less related to native species are more invasive. PNAS, 103, 58415845.

Thompson, J.N., Reichman, O.J., Morin, P.J., Polis, G.A., Power, M.E., Sterner, R.W. et al. (2001). Frontiers of Ecology. Bioscience, $51,15-24$. 
Turner, C.L. \& Knapp, A.K. (1996). Responses of a $C_{4}$ grass and three $C_{3}$ forbs to variation in nitrogen and light in tallgrass prairie. Ecology, 77, 1738-1749.

Vilà, M. \& Weiner, J. (2004). Are invasive plant species better competitors than native plant species? - evidence from pair-wise experiments. Oikos, 105, 229-239.

Vitousek, P. (1994). Beyond global warming: ecology and global change. Ecology, 75, 1861-1877.

Wedin, D.A. \& Tilman, D. (1996). Influence of nitrogen loading and species composition on the carbon balance of grasslands. Science, 274, 1720-1723.

Wilsey, B.J. (2005). Importance of species replication to understanding plant invasions into North American grasslands. In: Plant Invasions: Ecological and Agricultural Aspects (ed. Inderjit). Birkhäuser, Basel, Switzerland, pp. 61-76.

Wilsey, B.J. \& Polley, H.W. (2003). Effects of seed additions and grazing history on diversity and aboveground productivity of sub-humid grasslands. Ecology, 84, 920-932.

Wilsey, B.J. \& Polley, H.W. (2004). Realistically low species evenness does not alter grassland species richness-productivity relationships. Ecology, 85, 2693-2700.

Wilsey, B.J. \& Polley, H.W. (2006). Aboveground productivity and root-shoot allocation differ between native and introduced grass species. Oecologia, 150, 300-309.
Wilsey, B.J. \& Potvin, C. (2000). Biodiversity and ecosystem functioning: importance of species evenness in an old field. Ecology, 81, 887-893.

Wilsey, B. \& Stirling, G. (2007). Species richness and evenness respond in a different manner to propagule density in developing prairie microcosm communities. Plant Ecol., 190, 259-273.

Wolfe, B.E. \& Klironomos, J.N. (2005). Breaking new ground: soil communities and exotic plant invasion. Bioscience, 55, 477-487.

Zavaleta, E.S. \& Hulvey, K.B. (2004). Realistic species losses disproportionately reduce grassland resistance to biological invaders. Science, 306, 1175-1177.

Zavaleta, E.S. \& Hulvey, K.B. (2007). Realistic variation in species composition affects grassland production, resource use and invasion resistance. Plant Ecol., 188, 39-51.

Editor, Helmut Hillebrand

Manuscript received 13 October 2008

First decision made 13 November 2008

Second decision made 22 January 2009

Manuscript accepted 6 February 2009 